\title{
Problems and Prospects of Municipal Holding Taxation System: A Study on Bhairab Pourashava
}

\author{
Md. Samiul Huda* \\ Muhammad Rashidul Hasan **
}

\begin{abstract}
Local governments in Bangladesh have several options at hand to finance their activities and pursue their fiscal policy. These options include the imposition of taxes and the generation of non-tax revenues through fees, levies, cost recovery and user charges, property and investment income, domestic and foreign borrowing, the sale of assets and domestic and foreign grants. Urban Local Governments (ULGs) in developing countries are in dire need of resources not only for investment to meet the increasing demand of growing urban population but also for maintenance of the existing services. But the resources of the municipal bodies are inadequate; infrastructures are in poor condition and services maintenance is neither enough nor would cover the new expansions. Inefficient governance of the municipal bodies is partly responsible for this. Holding tax plays an important role in own revenue of Pourashavas. About 35-45\% revenue comes from holding tax. But in Bhairab Pourashava it contributes only $18-20 \%$. Every year, its demands and collection are decreasing. Many factors are responsible for this. This study tries to find out the problems of holding tax collection and assessment. Pourashava requires to pay more attention to solve these problems. If the amount of holding tax is increased, this will help Pourashava gradually become self-financed.
\end{abstract}

\section{Introduction}

With the rapid urban growth all over the world, the demand for various services and facilities are increasing radically. But due to resource constraint, authorities can not provide all these services. Financial support is necessary to provide these facilities. The municipality has to depend on its own revenue collection. There are two types of revenue - tax revenue and non-tax revenue. In tax revenue, holding tax plays an important role. Two-third of tax revenue comes from holding tax.

The resources of the municipal bodies are inadequate, infrastructures are in poor condition and maintenance of services is neither enough nor covers the new expansion. It also failed to make the reluctant residents to pay taxes. The shortage of finance has always plagued the urban government in attaining the optimum level of infrastructure and basic services. Under the present system, few urban government units are capable to generate sufficient resources to meet their capital and recurrent costs. Moreover, they have little incentive to take responsibility for their actions, including the collections of taxes (Chowdhury, 2004).

In Bangladesh, municipalities need to rely on the fixed amount allocated in the annual budget. Except some municipalities, none has potential earning sources (like harbor, expensive hotels, airports, etc) excluding taxation. Again the sources of collecting tax are limited. Holding tax is the part of property tax and everyone has to pay it. But the amount is not increasing according to the population size because of the ineffectiveness in revenue collection. Municipality has its own ordinance and under the ordinance there are some specific rules. Any municipalities may collect/gather fiscal amount by enforcing these rules/laws. So, efficient law enforcement will certainly raise the amount of holding tax. It is important for municipalities to introduce a standard and consistent policy for collecting accounts receivables, and for dealing with delinquent and defaulting payers. By instituting consistent policies and procedures, customers and taxpayers may

** Student, Urban and Rural Planning Discipline, Khulna University, Khulna.

** Town Planner, Bhairab Pourashava, Bhairab, Kishoreganj. 
be encouraged to pay their due taxes to avoid actions against non-payment (Samad, 2007). The main objective of this study is to overview the existing scenario of holding taxation system and to identify the problems of holding taxation system in Bhairab Pourashava.

\section{Methodology}

This study was conducted in November, 2008. The study had been divided in to three stages. In the first stage, the research problems were selected on municipal taxation for focusing the problems and giving highlights on prospects of municipal taxation. Conceptualization had been made with supervisor, other researchers who worked on research problem related to this study and personnel of related institutions like Municipality, LGED, and NILG etc. In the second stage, two sets of questionnaire were prepared for data collection, one for household survey and the other is for institutional survey. Stratified random sampling technique was followed to collect data from the inhabitants of the study area. After completing the field work, data was processed and presented in Tables and Figures. In the third stage, the data analysis was completed, which helped the examination of existing state of tax base and tax administration. After evaluation of the existing situation, the reasons of problems in tax administration were identified.

\section{Existing Scenario of Holding Tax in Bhairab Pourashava}

Present Revenue income of the Pourashava is derived from the following sources:

Demand based: Holding tax on land, building, conservancy, and lighting contribute in the demand based sources.

Cash based: Taxes, Fees, Rents, Leases, Earnings, Licenses, Sales, etc. are the cash based sources of revenue.

In addition, the Pourashava receives grants from the Government for both revenue and development expenditure. As specified above for holding taxes, demands are raised by issuing bills on holdings. The remaining incomes are earned from cash collection. Revenue receipts grew by $17 \%$ in $2007-08$ over $2005-06$ and by $10 \%$ in the year 2006-07 over 2005-06. Table 1 shows the information.

Table 1: The annual receipts of the Pourashava (both development and revenue) in last three years

\begin{tabular}{|l|c|c|c|}
\hline Receipts & $2005-06$ & $2006-07$ & $2007-08$ \\
\hline Revenue & 17.02 & 18.72 & 19.96 \\
\hline Development & 45.94 & 23.55 & 58.59 \\
\hline Total & 62.95 & 42.27 & 78.56 \\
\hline$\%$ increase over previous year & $100 \%$ & $-33 \%$ & $86 \%$ \\
\hline
\end{tabular}

Source: Field Survey, 2008

\section{Demand and Collection of Holding Tax}

Though holding tax plays an important role in own revenue income of a Pourashava, but in Bhairab Pourashava the scenario is not like that. The demand and collection of holding tax is decreased every year and the contribution of holding tax in the revenue of the Pourashava is not so appreciable. 


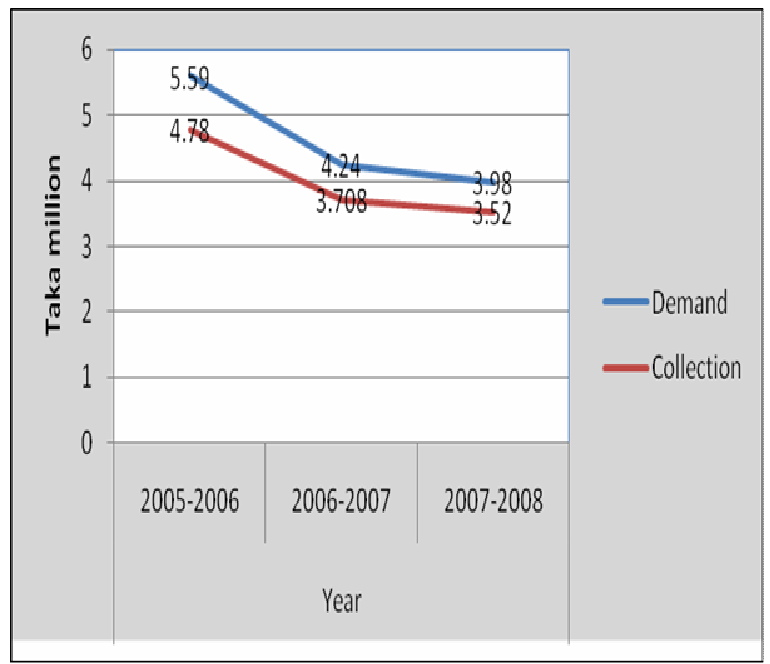

Fig. 1: Demand and collection of Holding tax from 2005 to 2008

Figure 1 shows the trend of demand and collection of holding tax, from 2005 to 2008 . The demand and collection was Tk.5.59 and Tk.4.78 million. But the demand and collection are decreased every year. It is a major problem for the Bhairab Pourashava. Holding tax still contributes a large portion of income for Bhairab Pourashava.

\section{Quantity of Holding Tax in Total Revenue of Bhairab Pourashava}

In 2005-2006, the total receipts was Tk.62.95 million, in which own revenue was Tk.17.02 million. But in 2006-2007, the total receipts were decreased at Tk.42.27 million, in which total own revenue income was Tk.18.72 million. In 2007-2008, the total receipt was increased at Tk.78.56 million. In 2006-2007, the total receipts decreased by $33 \%$ and in 2007-2008, it increased by $86 \%$. Figure 2 shows the information.

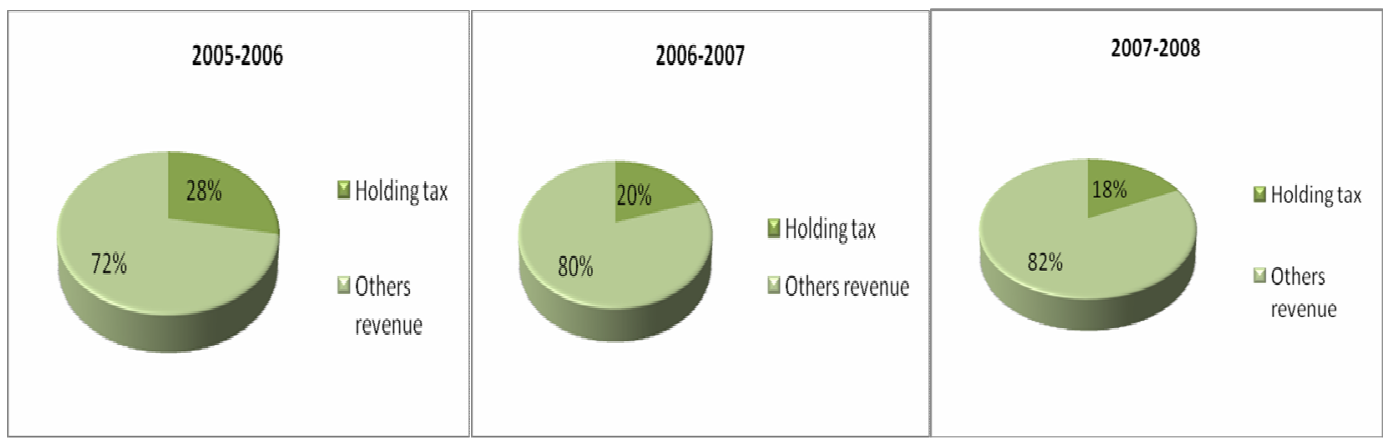

Fig. 2: Contribution of holding tax in own revenue.

In Figure 2, it can be observed that the own revenue income of the study area is increased every year but the contribution of holding tax in own revenue is decreased every year. The holding tax contributes only $18 \%$ of own revenue of the study area. In 2005-2006, the contribution was $28 \%$. But in 2007-2008, it decreased to $18 \%$. It is the most serious problem for any Pourashava as the holding tax is one of the main income sources of the Pourashava. 


\section{Expenditure of the Pourashava in the previous three years}

The yearly expenditures of the Pourashava are in the nature of staff salary, administrative expenses, operation and maintenance of equipment, finance expenses, other Pourashava services such as health, sanitation and waste management, maintenance of infrastructure, development expenditure etc. Expenditure on development account involves program implementation.

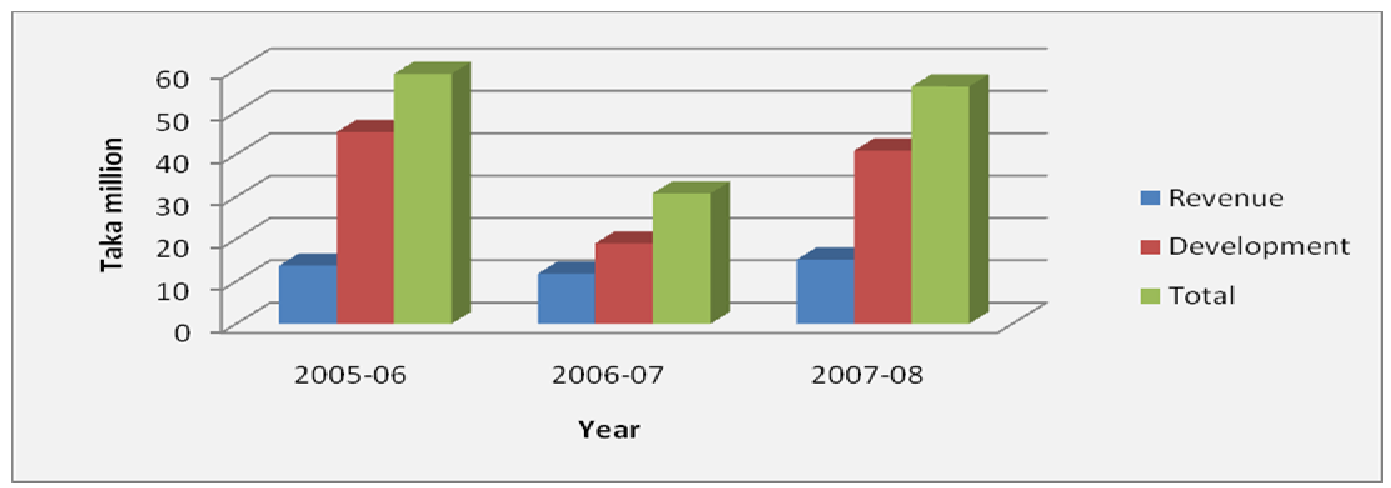

Fig. 3: Expenditure (both capital and revenue) of the Pourashava in the previous three years

In Figure 3, it is shown that in 2005-2006 total expenditure was Tk.59.05 million. But in 20062007, total expenditure decreased. In 2006-2007, the total expenditure was Tk. 30.82 million, and in 2007-2008, total expenditure increased to Tk.56.07 million. In the total expenditure, the revenue expenditure decreased at a systematic rate. Revenue expenditure rose by $10 \%$ in the year 2007-08 over 2005-06. So, it can be said that the expenditure of the Pourashava is increased.

Table 2: Revenue surplus of the Pourashava in last three years

\begin{tabular}{|c|c|c|c|}
\hline Surplus & $2005-06$ & $2006-07$ & $2007-08$ \\
\hline Revenue surplus & 3.26 & 6.89 & 4.80 \\
\hline$\%$ of revenue & $19 \%$ & $37 \%$ & $24 \%$ \\
\hline
\end{tabular}

(Source: Bhairab Pourashava, 2008)

Surplus generation in the last three years was Tk.14.95 million. The Pourashava is dependent on Government support for program implementation. During the period, Tk.27.53 million was received from the government for program implementation. In the year 2005-06, the carry forward balance of development account was Tk. 3.58 million, and development expenditure during the period was Tk. 105.19 million including UGIIP project.

\section{Process of holding tax assessment}

Taxes and rates are charged in terms of the percentage of the annual value of buildings and lands, conservancy rates and street light in Bhairab Pourashava. In the study area, there are appointed assessor and assistant assessor as regular employees who prepare the assessment valuation list both for regular assessment and general assessment/reassessment. The method of rental valuation is employed in reassessing properties in the Bhairab Pourashava like other Pourashava of Bangladesh as per the Municipal Committee (Taxation) Rules, 1960. Although according to the Pourashava Taxation Rules, 1960 annual value is determined by the submission of forms which includes returns of rent, the correct description of the building from owners and the inspection of 
the assessor to justify it. The tax assessors seldom go for checking the actual rent. In the study area, the assessors generally ask the house owner, but in some cases the tenants inform the rental rate of a house. The rental value per unit of building space for different types of structures, are then applied somewhat judgmentally, to other similar structures in the area. In case of publication of notice for assessment, very few public announcements are done by the authority in the locality (Field survey, 2008). As local representatives, the mayor and the ward commissioners are very well known to the people, who can easily serve such types of notice. The tax payers are allowed to appeal against assessed value within one month of the preparation of the assessment list (Municipal Committee Taxation Rules, 1960).

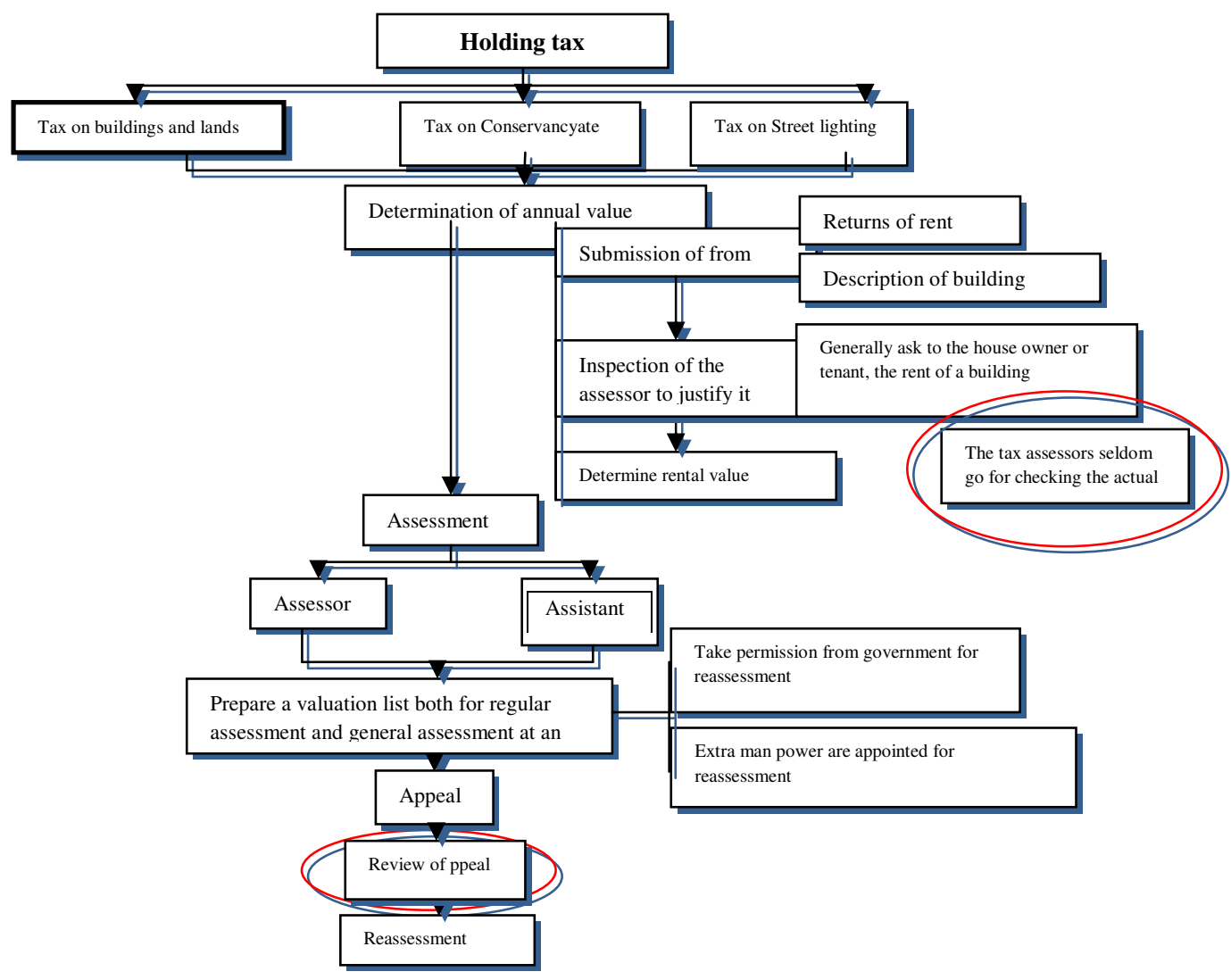

Fig. 4: Assessment Process

\section{Collection of Holding Tax:}

The Municipal authority delivers tax collection form to every holding for collecting taxes. The taxpayers may also be able to pay their own taxes to the Municipality directly through bank or through broker and agent. The tax is payable at the maximum of four installments per year. Section 10 of the Municipal Committee (Taxation) Rules, 1960 provides a rebate of $10 \%$ if the entire tax is paid within the first quarter of a year and a $5 \%$ rebate if the respective quarterly payments are made within that quarter. The tax payer is supposed to pay the taxes with a $5 \%$ annual surcharge attached with that whenever a tax payer fails to pay the taxes within the official time period. Municipality serves notices to the defaulters to pay taxes within 15 days. If the taxes are not paid within this period, a Distress Warrant (DW) is issued under section 38 of Municipal 
Administration Ordinance, 1960 (the rule 12-15 of the Taxation Rules), which allows the Municipality to sell all or a portion of defaulter's movable property at auction on the spot or afterwards depending on the value of the property. But such type of action is not done at all by the municipality (Field survey, 2008).

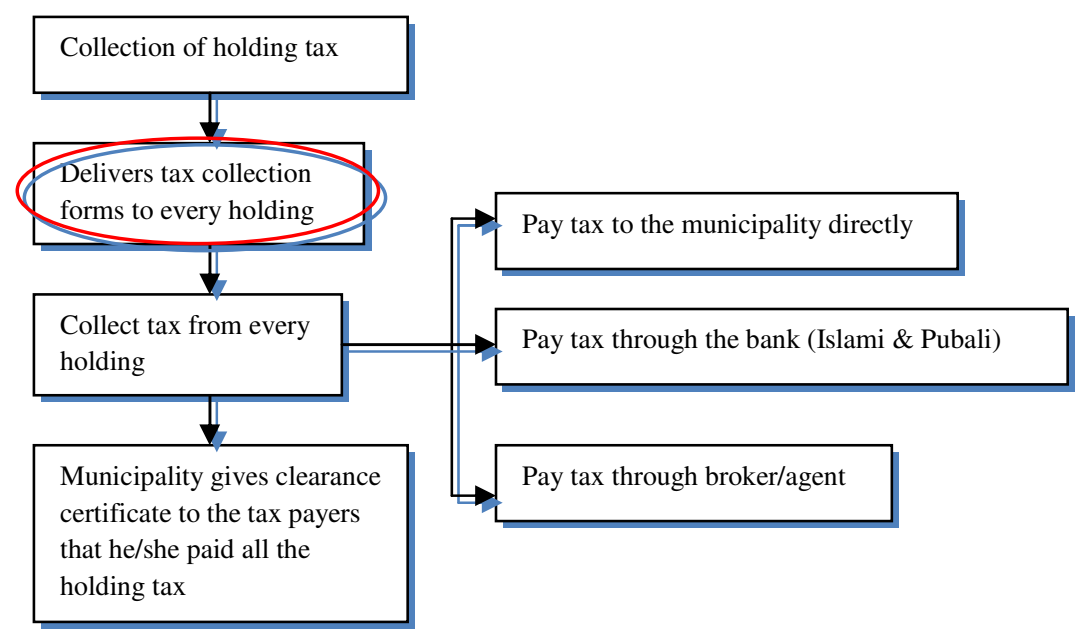

Fig. 5: Collection of holding tax

\section{Computerization of holding tax system}

Holding tax administration, with its huge database is a regular need for updating information through computerization. Maintaining a fiscal cadastre with information of households of holdings and updating it with the latest change in status such as change in tax payment and arrears in itself is a huge task. An encouraging factor is that Bhairab Pourashava has already introduced computers under the IDA-funded Municipal Services Project (MSP). Pourashavas have received a number of computers under MSP for managing tax billing and collection, water billing and collection systems and for general accounting purposes. Consultants under the Municipal Support Unit (MSU) have developed software for holding tax collection billing and collection system. The software has already been installed in Bhairab Pourashava.

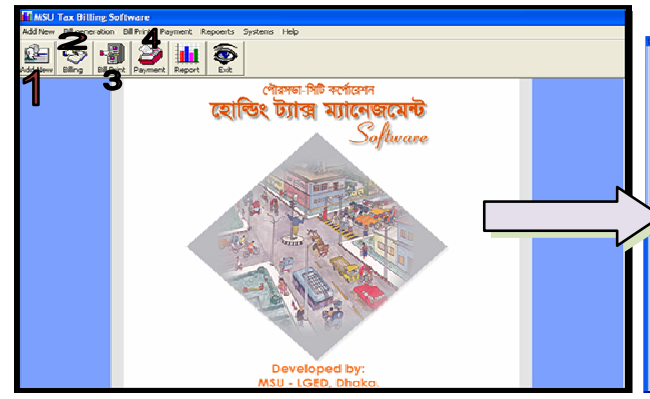

Fig. 6: Software for holding tax billing and collection
1

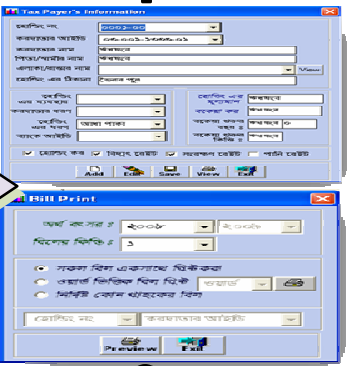

3
2

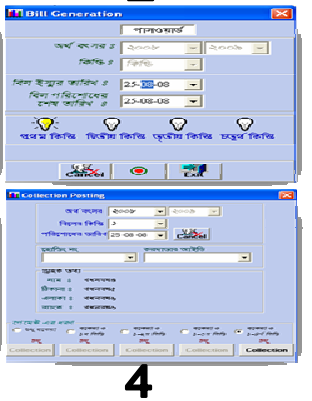

\section{Problems in Holding Tax Assessment and Collection}

In this study, problems are divided into two categories.

1) Problems associated with assessment of holding tax.

2) Problems associated with collection of holding tax. 


\section{Problems associated with assessment of holding tax}

Ownership identification: Ownership identification for imposition of property tax is the major reason for the problem of determining annual rental value. In case of joint ownership, tax imposition may sometimes become a problem. Some of the owners in the non-income group may actually be unable to pay taxes. But in case of income earners, the problem arises as to who should pay on other's behalf. Again, there may be absentee land owners. The tenant or agent of a property may not like to pay tax. Little initiatives are undertaken by the Pourashava to solve these problems.

Irregularity of assessment: In case of record keeping during reassessment, the assessor can not keep complete record when an addition to a building is made and rent value is increased. In the study area, appointed assessor and assistant assessor prepare the assessment valuation list both for regular assessment and general assessment or reassessment that is done periodically at an interval of five years. But regular assessment is seldom performed by them. Since property does not become taxable until it is build upon, it is not easy to say who would be liable for tax payments without watching regularly the new constructions, additions and alterations. Lack of information makes it difficult to change additional tax on a person even when it has become due on him. This situation also increases the possibility of corruption and tax evasion. Again because of irregular maintenance of collecting information and records, some of the holdings cannot physically be identified.

Illicit collusion between tax payer and assessor: Because of the illicit collusion between tax payer and assessor, the rental value per unit of building space for different types of structures are applied, somewhat judgmentally, to other, similar structures in the area which indicates a great undervaluation in property assessment in all jurisdiction. It was, however, not the purpose of this study to look into assessment of how much property value is undervalued for such reason.

Lack of political will: One of the fundamental reasons that hinder regular assessment is fear of adversely affecting the popularity of the elected officials of the Pourashavas. The elected officials seem to believe that regular reassessment would certainly increase tax burden on the Pourashava holdings, which in turn would jeopardize their chance of re-election. Interestingly, the same fear haunts Pourashava officials of the other countries, too.

Lack of assessors: The most striking feature of the current assessment regime is severe deficiency in human resources. The quality and quantity of assessment resources of the Pourashavas are simply inadequate to perform the job.

Indicators for holding tax assessment problems: The following indicators may be used:
a) Regularity of assessment
b) Information gap between tax payer and assessors
c) Political will
d) No of assessors
e) Ownership identification

Overall condition of indicators of holding tax assessment problems: With the help of likert method, the satisfaction level of these indicators was measured.

Table 3 presents that people's observations in holding tax assessment problems, for every indicator shows its own value in respect to Likert scale. Every indicator gets a weight individually by comment of experts. So, the problems get their weight $0.025,0.4,0.2, .75 \& 0.4$ respectively. From the likert scale, the total score have been found 2.2, which mean the holding tax assessment process is not satisfied. 


\section{Problems associated with collection holding tax}

Irregularity of billing: In the study area, tax collectors deliver the tax bills from door to door. Investigation revealed that tax bills are not regularly handed over to the tax prayers. Authority can not properly execute its duty frequently, because of the indolence of the municipal officials. From the field survey it is found that about $40 \%$ people do not get the bills in an appropriate time. They get the bill 2 or 3 months later after the preparation of the assessment list.

Table 3: Peoples' observation in indicators of assessment of holding tax

\begin{tabular}{|c|l|c|c|l|}
\hline Statement No. & \multicolumn{1}{|c|}{ Indicator } & $\begin{array}{c}\text { Likert } \\
\text { Score (s) }\end{array}$ & Weight(w) & \multicolumn{1}{|c|}{ WS } \\
\hline 01 & Ownership identification & 1.96 & 0.3 & 0.588 \\
\hline 02 & Regularity of assessment & 1.88 & 0.025 & 0.047 \\
\hline 03 & Gap between tax payer and assessor & 2.13 & 0.2 & 0.426 \\
\hline 04 & Political will & 2.95 & 0.075 & 0.22 \\
\hline 05 & Assessors & 2.31 & 0.4 & 0.924 \\
\hline Totals & & & & 2.200 \\
\hline
\end{tabular}

\begin{tabular}{|c|c|c|c|c|c|}
\hline Priority & Very satisfied & satisfied & Fairly & Less satisfied & Not satisfied \\
\hline Weight (b) & 5 & 4 & 3 & 2 & 1 \\
\hline
\end{tabular}

Ignorance of people: Most of the people do not know about the rate of the holding tax and the collection procedure of the holding tax. From the field survey, it was found that only $28 \%$ of the households knew about holding tax rate. One the other hand, only $9 \%$ households know about the holding tax collection procedure. So they have a little chance to know what should be the correct holding tax rate. So, very few people appeal against assessment. Ignorance has great impact on assessment procedure too. At the time of filling the forms, people do not provide the actual information they have to put. They put the information based on their assumption.

Unfavorable collection procedure: Collection procedure is followed by both manually and through bank in the study area. In case of manual dealings, there is scope for occurring corruption, especially tax evasion, which is occurred because of the illicit collusion between tax payer and collectors.

Lack of political will to enforce penalties: There is a punitive way of tax collection available to the Municipality. Government empowered the Municipality to recover all arrear through Distress Warrant (DW), sale of movable property or even by attachment and sale of immovable property belonging to the person concerned. But in all the studied year in this research, there is no record of distressed sale of property although there is record of few DWs served to collect arrear dues. There is no regular system of serving DWs. No time dimension is maintained for serving DWs nor there is any fixed minimum amount set to serve warrants (Ahmed, 1992). This indicates that there is lack of political will and initiatives to enforce penalties permitted by law. Some indicators may be useful for overseeing the holding tax collection process. The following are the indicators:

a) Regularity of billing

b) Motivational activities of Pourashava 
c) Collection procedure

d) Political will to enforce penalties

Overall condition of indicators of holding tax collection problems: With the help of likert method, the satisfaction level of these indicators was measured.

Table 4: Peoples findings for indicators of assessment of holding tax

\begin{tabular}{|l|c|l|l|}
\hline Indicators & Likert score(s) & Weight $(\mathrm{w})$ & WS \\
\hline Regularity of billing & 1.76 & 0.2 & 0.352 \\
\hline Motivational activities of Pourashava & 2.02 & 0.3 & 0.606 \\
\hline Collection procedure & 3.08 & 0.1 & 0.308 \\
\hline Political will to enforce penalties & 1.69 & 0.4 & 0.676 \\
\hline Total & & 1.942 \\
\hline
\end{tabular}

\begin{tabular}{|l|c|l|c|c|c|}
\hline Priority & Very satisfied & satisfied & Fairly & Less satisfied & Not satisfied \\
\hline Weight (b) & 5 & 4 & 3 & 2 & 1 \\
\hline
\end{tabular}

After the calculation with the help of likert scale, the total score is 1.942. It represents that the collection process of holding tax in the Bhairab Pourashava is not satisfied.

Problems in computerized holding tax system

Several obstacles are seemingly responsible for slowing down the process of computerization holding tax process in the Bhairab Pourashava (Figure 7). Perceived stumbling blocks are:

Lack of skill and training of the operators for handling computers

In the software, it shows only the information of any buildings. There is no option for showing information in the map and thus to find out buildings location is time consuming

$\square$ No printing option for installments, rebate and surcharge in the software.

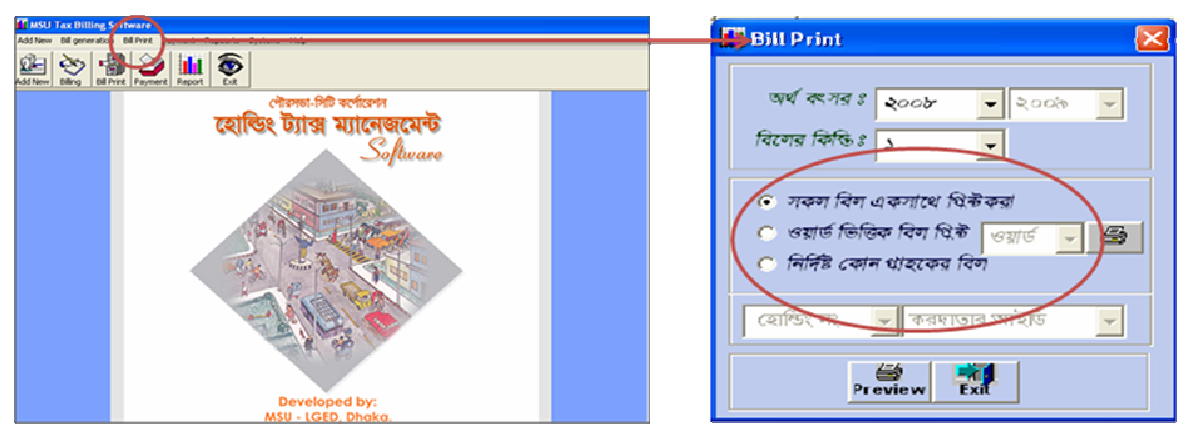

Fig. 7: Problems in computerized holding tax

\section{Conclusion}

It can be concluded that the holding tax collection performance of the Bhairab Pourashava is not so good. Though holding tax plays an important role in own revenue income of a Pourashava, but 
in Bhairab Pourashava, the scenario is not like that. The demand and collection of holding tax are decreased every year of the study area. And the contribution of holding tax in own revenue of the Pourashava is not so good. Many factors are responsible for this problem. This study tries to identify these factors and with the help of likert scale and these factors are ranked in order.

The problems associated with holding tax assessment and collection seem to be systematic in nature. Time and resource consuming assessment process results in predictable delays in reassessment, which is one of the major reasons for revenue losses to the Pourashavas. Furthermore, individual valuation of holdings with its attendant subjective nature made the process vulnerable to widespread corruption.

Various research reports are prepared by the government or donors in order to improve the holding tax performance which the municipality does not undertake. There is scope for improvement of holding tax improvement of the municipality. A systematic improvement in every aspect of the municipality is needed for this. The solution of almost all the problems lie in terms of increased initiative with elected municipal representatives and the permanent staff within the respective jurisdictions and not outside these.

\section{References}

Ahsan, S. M. M. 2002. Municipal Finance of a Small Town in Bangladesh: A case study of Magura Pourashava. Urban and Rural Planning Discipline, Khulna University, . Khulna.

Asher, M. G. 2002. The Design of Tax Systems and Corruption. Singapore: National University of Singapore.

Dirie, M. I. 2005. Municipal Finance: Innovative Resourcing for Municipal Infrastructure and Service Provision

LGED 2001 Paurashava Manual. Dhaka: Local Government Engineering Department (LGED).

LGED, 1999. Pourashava Manual, Secondary Towns Infrastructure Development Project - II, Dhaka: Local Government Engineering Department (LGED).

Mccullough, R. W. J. A. J. S. 1996. Case Study on Urban Local Government Finance.

Samad, R. 2007. Strengthening Revenue Earnings of Khulna City Corporation. Urban and Rural Planning Discipline, Khulna University, Khulna.

Siddiqui, K. 1994. Local Government in Bangladesh, Dhaka: University Press Ltd.

Yesin, A. P. 2004. Tax Collection Costs, Tax Evasion and Optimal Interest Rates. Switzerland: Study Center Gerzensee. 